\title{
Uptake, transfer and distribution of silver and cobalt in tissues of the common cuttlefish Sepia officinalis at different stages of its life cycle
}

\author{
P. Bustamante ${ }^{1, *}$, J.-L. Teyssié ${ }^{2}$, B. Danis ${ }^{3}$, S. W. Fowler ${ }^{2}$, P. Miramand ${ }^{1}$, \\ O. Cotret $^{2}$, M. Warnau ${ }^{2}$ \\ ${ }^{1}$ Laboratoire de Biologie et Environnement Marins, FRE 2727 du CNRS, Université de La Rochelle, 22, \\ Avenue Michel Crépeau, 17042 La Rochelle, France \\ ${ }^{2}$ Marine Environment Laboratory, International Atomic Energy Agency, 4 Quai Antoine $I^{\mathrm{er}}, 98000$, Monaco \\ ${ }^{3}$ Laboratoire de Biologie Marine, CP 160-15, Université Libre de Bruxelles, 50 Avenue F.D. Roosevelt, 1050 Bruxelles, Belgium
}

\begin{abstract}
Three pathways of exposure (sediment, seawater and food) were examined to determine transfer of ${ }^{110 \mathrm{~m}} \mathrm{Ag}$ and ${ }^{57} \mathrm{Co}$ in juvenile cuttlefish Sepia officinalis. Additional experiments were conducted on adult cuttlefish and their eggs/embryos in order to assess bioaccumulation patterns at different stages of the organism's life cycle. Eggs, juveniles and adults readily accumulated both Ag and Co from seawater. In eggs, both metals were predominantly adsorbed onto the capsule membrane ( $\geq 60 \%$ for Ag and $\geq 99 \%$ for Co), indicating that the latter may act as an effective shield to limit exposure of embryos to soluble metals. Adult cuttlefish incorporated waterborne radiotracers mainly in their muscular tissues ( $\geq 60 \%$ of the whole-body burden); subsequent metal retention was greater for Co (biological half-life, $\left.T_{\mathrm{b}^{1 / 2}}=34 \mathrm{~d}\right)$ than for $\mathrm{Ag}\left(T_{\mathrm{b}^{1 / 2}}=7 \mathrm{~d}\right)$ ). Turnover of Co ingested with food was much more rapid in juveniles $\left(T_{\mathrm{b}^{1 / 2}}=5 \mathrm{~d}\right)$ than in adults $\left(T_{\mathrm{b}^{1 / 2}}=990 \mathrm{~d}\right)$, suggesting that the functional maturation of the digestive gland was not complete in the juveniles. With ingested Ag, retention was roughly similar for juveniles and adults $\left(T_{\mathrm{b}^{1 / 2}}=13\right.$ and $9 \mathrm{~d}$, respectively). Transfer from sediments was negligible for Co and Ag. Regardless of the exposure pathway, the digestive gland of juveniles and adults contained the major fraction of incorporated metal either following uptake or after depuration. This observation demonstrates that substantial metal transfer takes place from several organs to the digestive gland, and further highlights the major role this organ plays in metal storage and detoxification processes in these cephalopods.
\end{abstract}

KEY WORDS: Metal $\cdot$ Radiotracer $\cdot$ Bioaccumulation $\cdot$ Digestive gland $\cdot$ Cephalopods Resale or republication not permitted without written consent of the publisher

\section{INTRODUCTION}

Interest in the bioaccumulation of trace elements in cephalopods stems mainly from their high trophic position in the marine food web, and from their role as important prey for marine mammals, seabirds and fish (Clarke 1996, Croxall \& Prince 1996, Klages 1996, Smale 1996). Furthermore, heavy metal levels in cephalopods, which are extensively fished and consumed by humans, are also of direct concern to public health. Various studies have investigated the concen- trations and tissue distribution of several trace metals in cephalopods (e.g. Martin \& Flegal 1975, Miramand \& Guary 1980, Miramand \& Bentley 1992, Bustamante et al. 2000, Ishihashi et al. 2001); however, most have been focused on essential trace elements or specific organs such as the digestive gland, the branchial hearts or the gills (see Miramand \& Bentley 1992). Owing to the high feeding rates characteristic of cephalopods, food has often been cited as the main uptake pathway for explaining the high concentrations of metals found in cephalopod tissues (e.g. Martin \& 
Flegal 1975, Bustamante et al. 1998, Gerpe et al. 2000). However, there are very few published studies that determine the assimilation efficiencies and depuration rate constants of trace metals in cephalopods (Suzuki et al. 1978, Guary \& Fowler 1982, Ueda et al. 1985, Bustamante et al. 2002a). These parameters are necessary in order to assess the degree of retention of waterborne and dietary metals and to assess the relative importance of both pathways. In addition, benthic cephalopods live in direct contact with the substratum, and many swimming species such as cuttlefish spend long periods buried into sediment (Mangold 1989). Therefore sediments should also be considered as a possible pathway for metal transfer to cephalopods.

$\mathrm{Ag}$ and Co have been reported to be concentrated, sometimes to a very large extent, in cephalopods (Martin \& Flegal 1975, Ueda et al. 1979); however, little is known about the metabolism of these 2 heavy metals. The digestive gland appears to contain most of the body burden of $\mathrm{Ag}$ and $\mathrm{Co}$ in squid (Ishihashi et al. 2001), in octopus and cuttlefish (Miramand \& Bentley 1992) and in nautilus (Bustamante et al. 2000). A large proportion $(>60 \%)$ of the $\mathrm{Ag}$ in digestive gland is located in the cytosolic fraction of the cells (Tanaka et al. 1983). To the best of our knowledge, no data are available in the literature regarding pathway-specific bioaccumulation (viz., water vs food bioaccumulation) of $\mathrm{Ag}$ and $\mathrm{Co}$ in these organisms. Therefore, the present work has focused on uptake and loss kinetics of $\mathrm{Ag}$ and $\mathrm{Co}$ in a cephalopod exposed via different routes in order to better characterise their bioaccumulation rates, the subsequent tissue distribution and their retention times depending on the uptake pathway. The common cuttlefish Sepia officinalis was selected as an experimental model, and contamination via seawater, food and sediment was studied in eggs/ embryos, juvenile and adult cuttlefish.

\section{MATERIALS AND METHODS}

Experimental organisms. Eggs of the common cuttlefish Sepia officinalis L. were obtained from cultured adults and maintained in an aquarium with flowing seawater until hatching. These newly hatched juveniles $(\mathrm{n}=25 ; 0.387 \pm 0.071 \mathrm{~g}$ wet $\mathrm{wt})$ were then used in the experiments. Adult cuttlefish $(\mathrm{n}=18 ; 138 \pm 40 \mathrm{~g}$ wet wt) were reared in the Oceanographic Museum (Principality of Monaco) from hatching to $1 \mathrm{yr}$ old, or collected by net fishing off Monaco $(\mathrm{n}=5 ; 253 \pm 97 \mathrm{~g}$ wet wt). Prior to any experimentation, adults were anaesthetised in seawater containing $2 \%$ ethanol for making biometric measurements, sex determination and for the insertion of a numbered plastic tag into the mantle fin to identify each animal during the experiments.
Radiotracers. Radiotracers ${ }^{110 \mathrm{~m}} \mathrm{Ag}\left[t_{1 / 2}=250.4 \mathrm{~d}\right]$ and ${ }^{57} \mathrm{Co}\left[t_{1 / 2}=271.8 \mathrm{~d}\right]$ were purchased from Amersham as nitrate and chloride salts, respectively. Stock solutions were prepared in their respective acids $(0.1 \mathrm{~N})$ to obtain radioactivities which would allow the use of spikes measuring only a few $\mu$ (typically 10 to $20 \mu$ l).

Ag and Co uptake in Sepia officinalis exposed via sediments. Sediments (2.5 kg dry wt) from the North Sea (Audresselles, Pas-de-Calais, France) were spiked for $4 \mathrm{~d}$ with ${ }^{110 \mathrm{~m}} \mathrm{Ag}$ and ${ }^{57} \mathrm{Co}$ using the rolling jar method (Murdoch et al. 1997). Before initiating the experiment, radiolabelled sediments were held in flowing seawater overnight in order to leach weakly bound radiotracer. Sediments (50 g wet wt) were sampled at fixed intervals during the experiment to check for possible variations in radiotracer concentrations. Juvenile cuttlefish $(n=9)$ were exposed for $29 \mathrm{~d}$ in a 201 plastic aquarium (constantly aerated open circuit

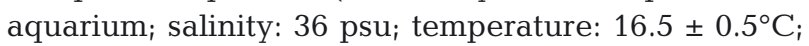
12:12 h dark:light cycle) containing ca. 31 of natural seawater running over a $4 \mathrm{~cm}$ layer of spiked sediments. The depth of seawater was maintained at a low level in order to minimise the movements required for feeding, and to maximise the time of contact with sediments. During the experiment, all juvenile cuttlefish were fed twice daily with Artemia salina and were periodically $\gamma$-counted to follow the radiotracer uptake kinetics over the $29 \mathrm{~d}$. At the end of the uptake experiment, 3 individuals were dissected to determine the distribution of the radiotracers among digestive gland, cuttlebone and remainder (rest of the organs).

Ag and Co uptake in Sepia officinalis exposed via seawater and subsequent loss. Eggs/embryos: Cuttlefish eggs were placed in a $70 \mathrm{l}$ glass aquarium containing natural filtered $(0.45 \mu \mathrm{m})$ seawater spiked with $6 \mathrm{kBq}{ }^{110 \mathrm{~m}} \mathrm{Ag} \mathrm{l}^{-1}(57 \mathrm{pM})$ and $6 \mathrm{kBq}{ }^{57} \mathrm{Co}^{-1}(0.68 \mathrm{pM})$ for $11 \mathrm{~d}$ (constantly aerated closed circuit; salinity:

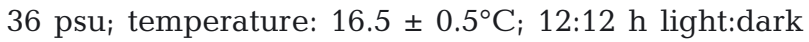
cycle). Radiotracers and seawater were renewed daily to maintain seawater quality and radiotracer concentrations as constant as possible. Radiotracer activities in seawater were checked daily (before and after seawater renewals). During the experiment, ${ }^{110 \mathrm{~m}} \mathrm{Ag}$ and ${ }^{57} \mathrm{Co}$ radioactivities were measured in the eggs on Days 1, 2, 3, 6, 9, and 11. At each time, 3 eggs were dissected to determine the distribution of the radiotracers among the capsule membrane, peri-embryonar liquid and embryo.

Juveniles and adults: Juvenile $(\mathrm{n}=8)$ and adult $(\mathrm{n}=$ 5) cuttlefish were placed for 36 and $8 \mathrm{~h}$, respectively, in $70 \mathrm{l}$ glass aquaria containing seawater spiked with ${ }^{110 \mathrm{~m}} \mathrm{Ag}$ and ${ }^{57} \mathrm{Co}\left(6 \mathrm{kBq} \mathrm{l}^{-1}\right.$ each). Cuttlefish were then radioanalyzed and transferred to another $70 \mathrm{l}$ aquarium supplied with natural flowing seawater (open circuit with constant aeration; seawater renewal: $20 \mathrm{l} \mathrm{h}^{-1}$; 


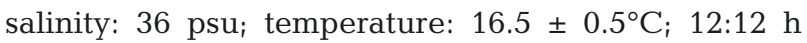
light:dark cycle). Juvenile cuttlefish were fed Artemia salina twice daily and were periodically $\gamma$-counted to follow radiotracer loss kinetics over $29 \mathrm{~d}$. At the end of the loss period, 4 juveniles were dissected to determine the radiotracer distribution among digestive gland, cuttlebone and remainder.

Adults were fed daily with soft parts of the mussel Mytilus galloprovincialis. Three adults were dissected after $8 \mathrm{~h}$ and the 2 remaining ones were dissected after $6 \mathrm{~d}$ depuration. For each individual, the branchial heart appendages, branchial hearts, gills, digestive tract (after removal of the gut contents), genital tract, ovary or testes, ink sac, digestive gland, kidneys, mantle skin, mantle muscle, head and cuttlebone were separated, weighed, and their radiotracer content measured.

Ag and Co bioaccumulation in Sepia officinalis from food. Different prey were selected to match as closely as possible to the size of the natural food of juveniles and adult cuttlefish (Mangold 1989). To prepare radiolabelled food, mussels Mytilus galloprovincialis and brine shrimp Artemia salina were exposed for $7 \mathrm{~d}$ in plastic aquaria containing $4 \mathrm{l}$ of natural seawater spiked with ${ }^{110 \mathrm{~m}} \mathrm{Ag}$ and ${ }^{57} \mathrm{Co}\left(6 \mathrm{kBq} \mathrm{l^{-1 }}\right.$ each). Radiolabelled seawater was renewed daily and the organisms were subsequently used as food for juvenile (brine shrimp) and adult (mussels) cuttlefish.

Juvenile cuttlefish ( $\mathrm{n}=8$ ) were held in a $70 \mathrm{l}$ glass aquarium (open circuit with constant aeration; seawater renewal: $201 \mathrm{~h}^{-1}$; salinity: $36 \mathrm{psu}$; temperature: $16.5 \pm 0.5^{\circ} \mathrm{C}_{i} 12: 12 \mathrm{~h}$ light:dark cycle). For identification purposes, each individual was enclosed in a separate compartment allowing free circulation of seawater. After $1 \mathrm{~h}$ of ingesting radiolabelled brine shrimp, each individual was immediately $\gamma$-counted. From that time on, cuttlefish were fed twice daily with noncontaminated Artemia salina and regularly $\gamma$-counted to determine radiotracer loss kinetics and assimilation efficiency. Throughout the depuration period (29 d), faeces were removed 3 times per day to reduce possible indirect contamination by radiotracer recycling through leaching from the faeces. At the end of the depuration period, 5 juveniles were dissected to determine the radiotracer distribution in their tissues.

Adult cuttlefish $(n=18)$ were held in a 30001 aquarium (open circuit with constant aeration; seawater renewal: $300 \mathrm{l} \mathrm{h}^{-1}$; salinity: $36 \mathrm{psu}$; temperature: $16.5 \pm$ $0.5^{\circ} \mathrm{C} ; 12: 12 \mathrm{~h} \mathrm{light/dark}$ cycle) and fed soft parts of the previously labelled mussels for $2 \mathrm{~h}$. Immediately after ingestion, each individual was $\gamma$-counted and the same procedure was followed as for the juveniles. In addition, 3 adult cuttlefish were dissected at each counting time to determine the radiotracer distribution among their organs and tissues.
Radioanalyses. Radioactivities of the tracers were measured using a high-resolution $\gamma$-spectrometry system consisting of coaxial Ge (N- or P-type) detectors (EGNC 33-195-R, Intertechnique) connected to a multichannel analyser and a computer with spectra analysis software (Interwinner). The detectors were calibrated with appropriated standards for each of the counting geometries used and measurements were corrected for background and physical decay of the radiotracers. Counting times were adapted to obtain relative propagated errors less than $5 \%$. However, in a few cases, this counting precision could not be obtained even after $48 \mathrm{~h}$ of counting, due to the very low activity in extremely small organs. Counting times ranged from $10 \mathrm{~min}$ to $1 \mathrm{~h}$ for whole cuttlefish, mussel and brine shrimp, and from $10 \mathrm{~min}$ to $48 \mathrm{~h}$ for the dissected organs and tissues.

Data and statistical analyses. Uptake of ${ }^{110 \mathrm{~m}} \mathrm{Ag}$ and ${ }^{57} \mathrm{Co}$ from seawater and sediments was expressed, respectively, as change in whole-body concentration factors $(\mathrm{CF})$ and transfer factors (TF) over time $\left(\mathrm{Bq} \mathrm{g}^{-1}\right.$ wet wt organism divided by the time-integrated $\mathrm{Bq}^{-1}$ in seawater, $\mathrm{CF}$, or sediments, $\mathrm{TF}$ ). Uptake kinetics in the eggs were described using a single-component first-order kinetic model (Eq. 1):

$$
\mathrm{CF}_{t}=\mathrm{CF}_{\mathrm{ss}}\left(1-\mathrm{e}^{-k t}\right)
$$

where $\mathrm{CF}_{t}$ and $\mathrm{CF}_{\mathrm{sS}}$ are concentration factors at time $t$ (d) and steady state, respectively, and $k$ is the depuration rate constant $\left(\mathrm{d}^{-1}\right)$ (Whicker \& Schultz 1982).

Radiotracer loss was expressed in terms of percentage of remaining radioactivity over time, i.e. radioactivity at time $t$ divided by initial radioactivity measured in the organisms at the beginning of the depuration period. Loss kinetics were described either by a singlecomponent exponential model (Eq. 2) or by a 2-component exponential model (Eq. 3):

$$
\begin{gathered}
A_{t}=A_{0} \mathrm{e}^{-k t} \\
A_{t}=A_{0 \mathrm{~s}} \mathrm{e}^{-k_{\mathrm{s}} t}+A_{01} \mathrm{e}^{-k_{1} t}
\end{gathered}
$$

where $A_{t}$ and $A_{0}$ are the remaining activities (\%) at time $t(\mathrm{~d})$ and 0 , respectively; the 's' subscript refers to a short-lived component (s component) and the ' $\mathrm{l}$ ' subscript refers to a long-lived component (l component) (Hubbell et al. 1965, Whicker \& Schultz 1982). The exponential model showing the best fit (based on calculation of the determination coefficients, $\mathrm{R}^{2}$, and examination of the residuals) was selected. In the case of radiotracer loss following ingestion of spiked food, the long-lived ' $\mathrm{l}$ ' component is a model of the loss of the radiotracer fraction that is actually assimilated by the organism. Thus, the constant $A_{01}$ is an estimate of the fraction of radioactivity (or metal) assimilated from food, i.e. the assimilation efficiency (AE) (Hubbell et al. 1965, Reinfelder et al. 1998). 
Depuration rate constant $k$ allows the calculation of the radiotracer biological half-life (d) using the following equation:

$$
T_{\mathrm{b}^{1 / 2}}=\ln 2 / \mathrm{k}
$$

Constants of the models and their statistics were estimated by iterative adjustment of the model and Hessian matrix computation, respectively, using the non-linear curve-fitting routines in the Statistica 5.1 Software. Changes in radiotracer distribution among cuttlefish tissues were tested for significance by the $G$-procedure (adapted from the log-likelihood ratio test) for $2 \times k$ contingency tables (Zar 1996). Changes in $\%$ of radioactivity in a single tissue during the depuration period were tested by 1-way ANOVA (after arcsin-transformation of data) followed by the Tukey's multiple comparison test. The significance level for statistical analyses was always set at $\alpha=0.05$.

\section{RESULTS}

\section{Sediment exposure}

Regular monitoring of radiotracer activities in sediment showed no significant variation during the experimental time course; time-integrated radioactivities were $14.7 \pm 1.2 \mathrm{~Bq} \mathrm{~g}$ wet $\mathrm{wt}^{-1}$ for ${ }^{110 \mathrm{~m}} \mathrm{Ag}$ and $45.5 \pm$ $3.4 \mathrm{~Bq} \mathrm{~g}$ wet $\mathrm{wt}^{-1}$ for ${ }^{57} \mathrm{Co}$. Uptake of ${ }^{110 \mathrm{~m}} \mathrm{Ag}$ in juveniles cuttlefish displayed linear kinetics during the experiment period, with TF reaching 1 after 29 d of exposure (Fig. 1A). In contrast, very low ${ }^{57} \mathrm{Co}$ activities were recorded in the same individuals, with maximum TF values of 0.013 (Fig. 1B). Dissection of 3 individuals after $29 \mathrm{~d}$ of exposure showed that, for both metals, the digestive gland contained the highest proportion of the whole body burden, i.e. $57 \pm 2 \%$ of ${ }^{110 \mathrm{~m}} \mathrm{Ag}$ and $79 \pm$ $0.3 \%$ of ${ }^{57} \mathrm{Co}$ (Table 1 ).
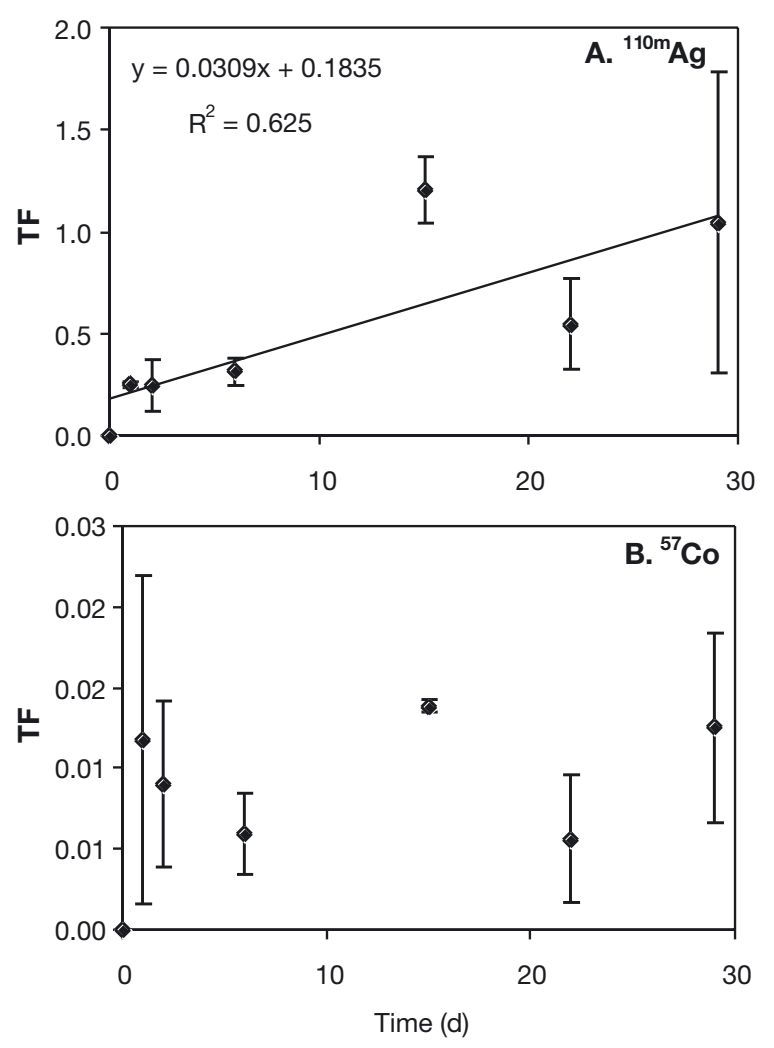

Fig. 1. Sepia officinalis. Whole-body uptake kinetics of (A) ${ }^{110 \mathrm{~m}} \mathrm{Ag}$ and (B) ${ }^{57} \mathrm{Co}$ in juvenile cuttlefish exposed to radiolabelled sediments (transfer factor, $\mathrm{TF}_{\text {; }}$ mean $\pm \mathrm{SD}, \mathrm{n}=9$ from Day 0 to 22, and $n=3$ on Day 29)

steady-state concentration factors $\left(\mathrm{CF}_{\mathrm{ss}}\right)$ in the eggs were $28.6 \pm 1.5$ for ${ }^{110 \mathrm{~m}} \mathrm{Ag}$ and $33.1 \pm 1.7$ for ${ }^{57} \mathrm{Co}$. During the experiment, the greatest proportion of both radiotracers was associated with the egg capsule membrane, viz. 57 to $84 \%$ for ${ }^{110 \mathrm{~m}} \mathrm{Ag}$ and $\geq 99 \%$ for ${ }^{57} \mathrm{Co}$ (Fig. 3).

\section{Seawater exposure}

Regular monitoring of radiotracer activities in seawater allowed calculation of time-integrated radioactivities, viz. $8.3 \pm 0.9$ and $5.8 \pm 0.3 \mathrm{kBq} \mathrm{l}^{-1}$ for ${ }^{110 \mathrm{~m}} \mathrm{Ag}$ and ${ }^{57} \mathrm{Co}$, respectively.

\section{Eggs}

Despite the relatively short experimental exposure $(11 \mathrm{~d})$, the uptake of both radiotracers clearly displayed saturation kinetics (Fig. 2). Estimated
Table 1. Sepia officinalis. Radiotracer distribution ( $\%$; mean $\pm \mathrm{SD}$ ) among 3 body compartments of juvenile cuttlefish (a) after a $29 \mathrm{~d}$ exposure to spiked sediments, (b) after a $29 \mathrm{~d}$ depuration following a $36 \mathrm{~h}$ exposure to spiked seawater, and (c) after a $29 \mathrm{~d}$ depuration following ingestion of spiked food (brine shrimp)

\begin{tabular}{|c|c|c|c|c|}
\hline \multirow{2}{*}{ Exposure pathway } & \multirow[t]{2}{*}{$\mathrm{n}$} & \multicolumn{3}{|c|}{ Body compartment } \\
\hline & & Digestive gland & Cuttlebone & Remainder \\
\hline (a) Sediments & 3 & & & \\
\hline${ }^{110 \mathrm{~m}} \mathrm{Ag}$ & & $57 \pm 2$ & $0.5 \pm 0.4$ & $43 \pm 3$ \\
\hline${ }^{57} \mathrm{Co}$ & & $79 \pm 0.3$ & $1.8 \pm 0.6$ & $19 \pm 1$ \\
\hline (b) Seawater & 4 & & & \\
\hline $110 \mathrm{~m} A g$ & & $69 \pm 11$ & $0.5 \pm 0.1$ & $31 \pm 11$ \\
\hline${ }^{57} \mathrm{Co}$ & & $78 \pm 1$ & $0.4 \pm 0.1$ & $22 \pm 1$ \\
\hline (c) Feeding & 5 & & & \\
\hline${ }^{110 \mathrm{~m}} \mathrm{Ag}$ & & $83 \pm 5$ & $0.9 \pm 0.7$ & $16 \pm 4$ \\
\hline${ }^{57} \mathrm{Co}$ & & $79 \pm 6$ & $0.8 \pm 0.8$ & $20 \pm 6$ \\
\hline
\end{tabular}



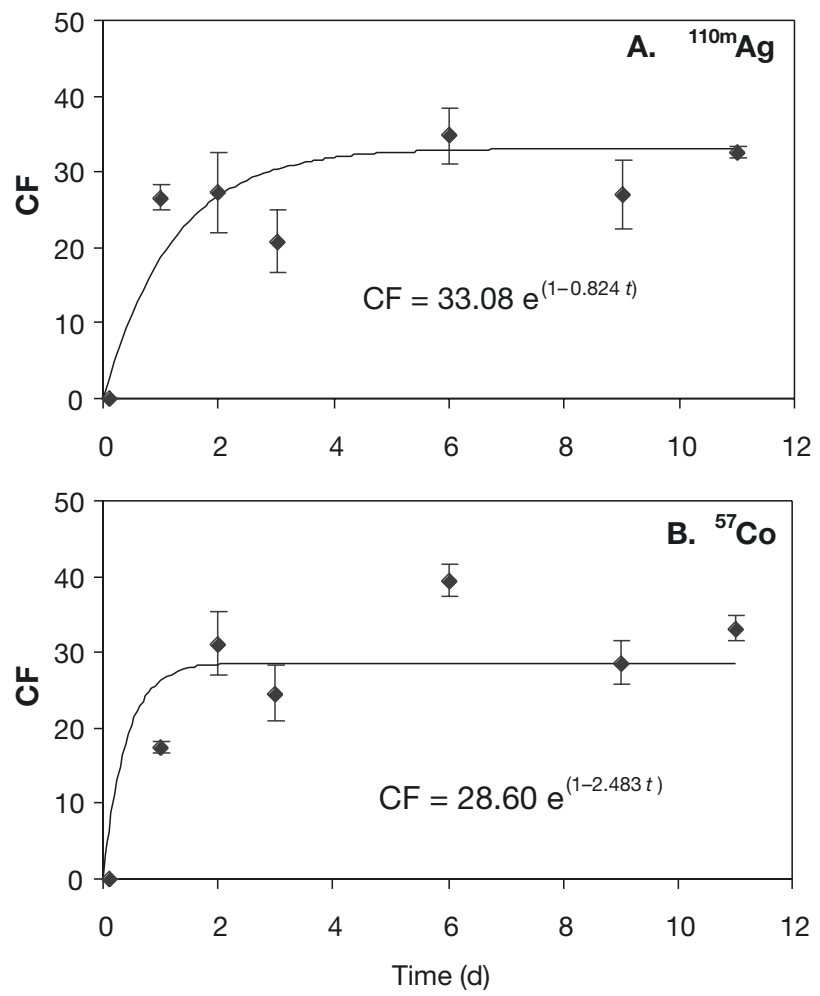

Fig. 2. Sepia officinalis. Whole-body uptake kinetics of (A) ${ }^{110 \mathrm{~m}} \mathrm{Ag}$ and (B) ${ }^{57} \mathrm{Co}$ in cuttlefish eggs exposed for $11 \mathrm{~d}$ to dissolved radiotracers in seawater (concentration factor, $\mathrm{CF}_{\text {; }}$ mean $\pm \mathrm{SD}, \mathrm{n}=3$ )

\section{Juveniles}

The activities measured in juveniles after $36 \mathrm{~h}$ of exposure via seawater were $2660 \pm 1040$ and $131 \pm$ $24 \mathrm{~Bq} \mathrm{~g}$ wet $\mathrm{wt}^{-1}$ for ${ }^{110 \mathrm{~m}} \mathrm{Ag}$ and ${ }^{57} \mathrm{Co}$, respectively. Mean calculated CF were elevated, viz. $320 \pm 125$ and $23 \pm 4$ for ${ }^{110 \mathrm{~m}} \mathrm{Ag}$ and ${ }^{57} \mathrm{Co}$, respectively. Following transfer to non-contaminated seawater, loss kinetics of both radiotracers in juvenile cuttlefish were best described by a single-component model (Fig. 4A,B, Table 2). Loss kinetics were characterised by $T_{\mathrm{b}^{1 / 2}}$ of $1 \mathrm{wk}$ for ${ }^{110 \mathrm{~m}} \mathrm{Ag}$ and $5 \mathrm{wk}$ for ${ }^{57} \mathrm{Co}$. At the end of the depuration period, both radiotracers were mainly associated with the digestive gland of the young cuttlefish (69 to $78 \%$ of whole-body activity), while the lowest fraction was deposited in the cuttlebone $(<1 \%$ of the total activity) (Table 1).

\section{Adults}

${ }^{110 \mathrm{~m}} \mathrm{Ag}$ and ${ }^{57} \mathrm{Co}$ activities recorded in the different organs and tissues of adult cuttlefish after $8 \mathrm{~h}$ of exposure and corresponding CFs are presented in Table 3.

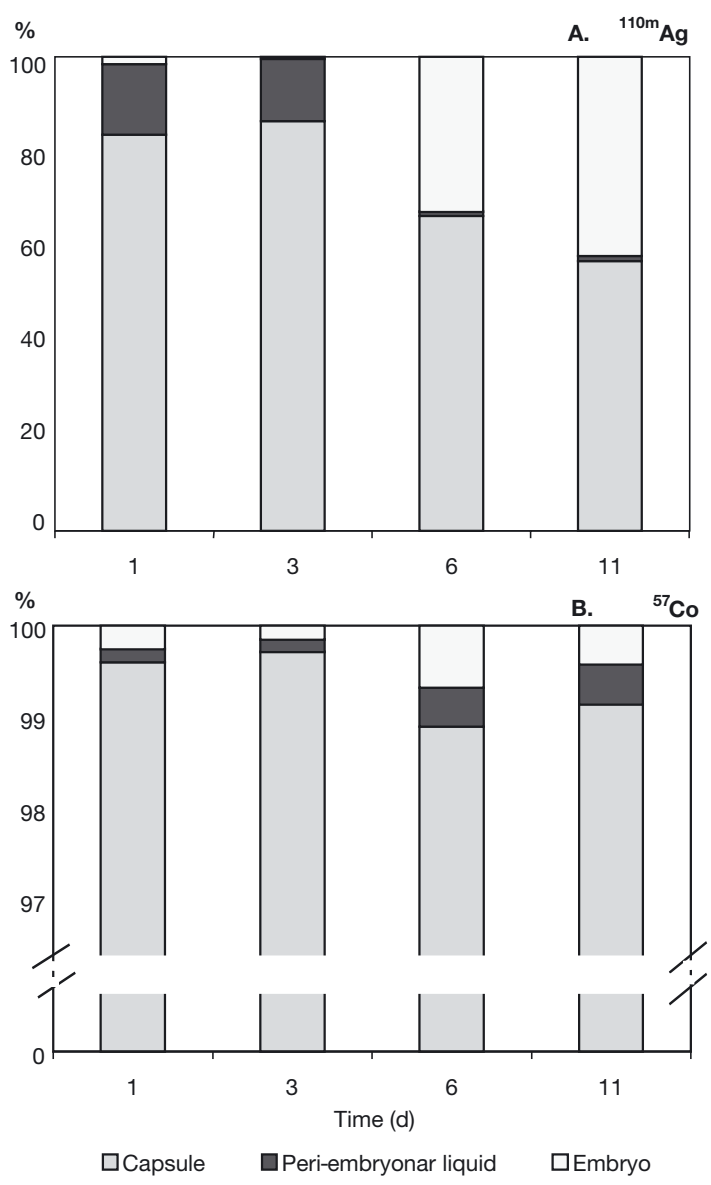

Fig. 3. Sepia officinalis. Distribution (\%; mean values) of (A) ${ }^{110 \mathrm{~m}} \mathrm{Ag}$ and (B) ${ }^{57} \mathrm{Co}$ among the cuttlefish egg compartments at different times during their exposure via seawater

The highest activities of ${ }^{110 \mathrm{~m}} \mathrm{Ag}$ were found in the gills (1253 $\pm 465 \mathrm{~Bq} \mathrm{~g}^{-1}$ wet wt) followed by branchial hearts and skin $\left(631 \pm 398\right.$ and $335 \pm 135 \mathrm{~Bq} \mathrm{~g}$ wet $\mathrm{wt}^{-1}$, respectively). In the case of ${ }^{57} \mathrm{Co}$, the digestive gland contained the highest activities, followed by branchial hearts and kidney $(86 \pm 77,70 \pm 12$, and $66 \pm 30 \mathrm{~Bq} \mathrm{~g}$ wet $\mathrm{wt}^{-1}$, respectively). When considering the tissue distribution of the radiotracer activities, muscular tissues of adults (i.e. sum of the mantle muscles, skin and head) were found to contain the highest proportion of ${ }^{110 \mathrm{~m}} \mathrm{Ag}$ and ${ }^{57} \mathrm{Co}, 66$ and $60 \%$, respectively (Table 3). The second highest fraction was found in the gills (25\% for $\left.{ }^{110 \mathrm{~m}} \mathrm{Ag}\right)$ and in the digestive gland $\left(20 \%\right.$ for $\left.{ }^{57} \mathrm{Co}\right)$.

The radiotracer distribution among the tissues varied greatly between the beginning and the end of the depuration period (Table 3). Indeed, the fraction of ${ }^{110 \mathrm{~m}} \mathrm{Ag}$ and ${ }^{57} \mathrm{Co}$ increased significantly over time $(\mathrm{p}<$ 0.001 ) in the digestive gland (from 5 to $61 \%$ and from 20 to $64 \%$, respectively). In contrast, tissues in direct 
Juveniles after seawater exposure
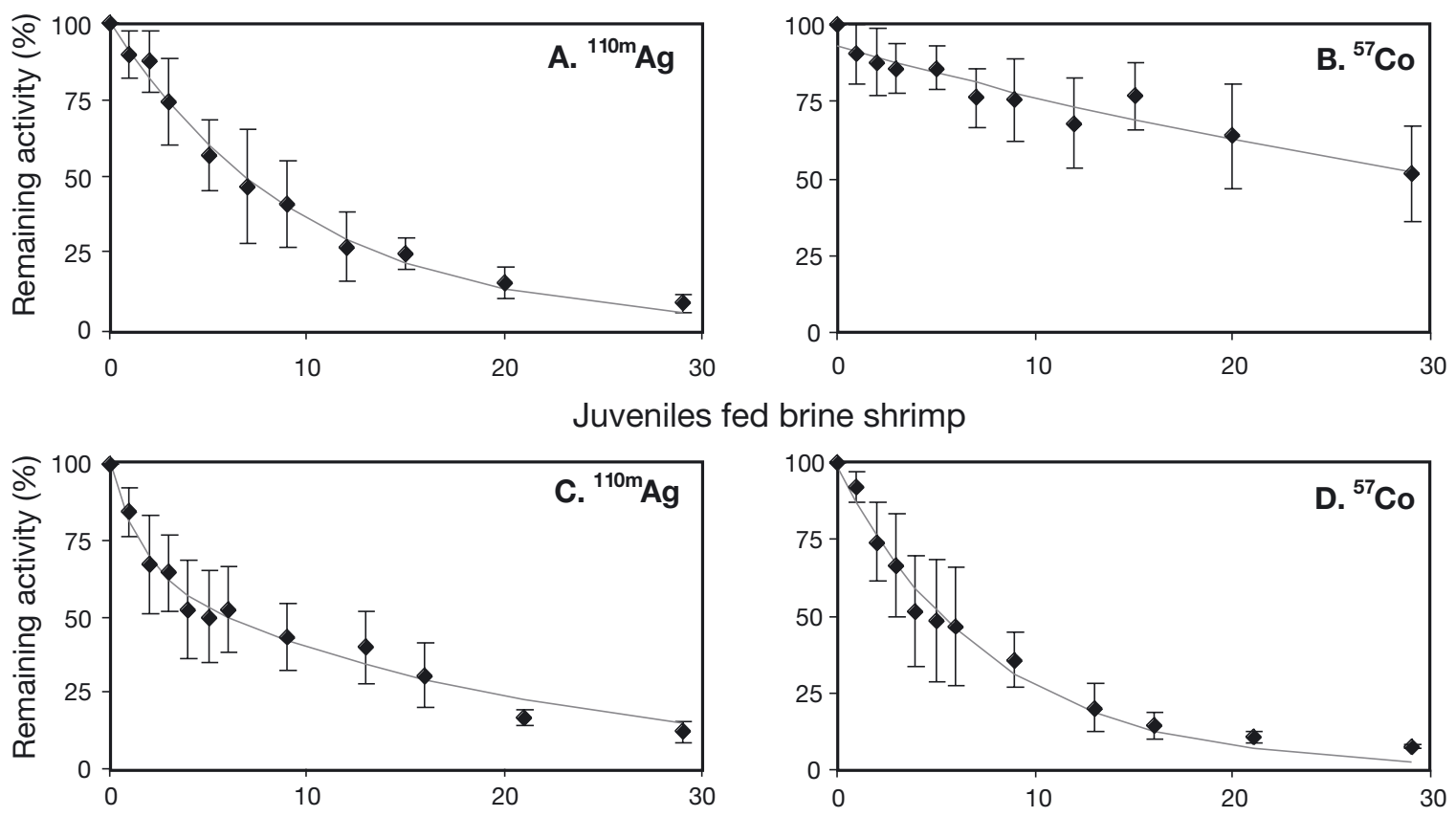

Adults fed mussels
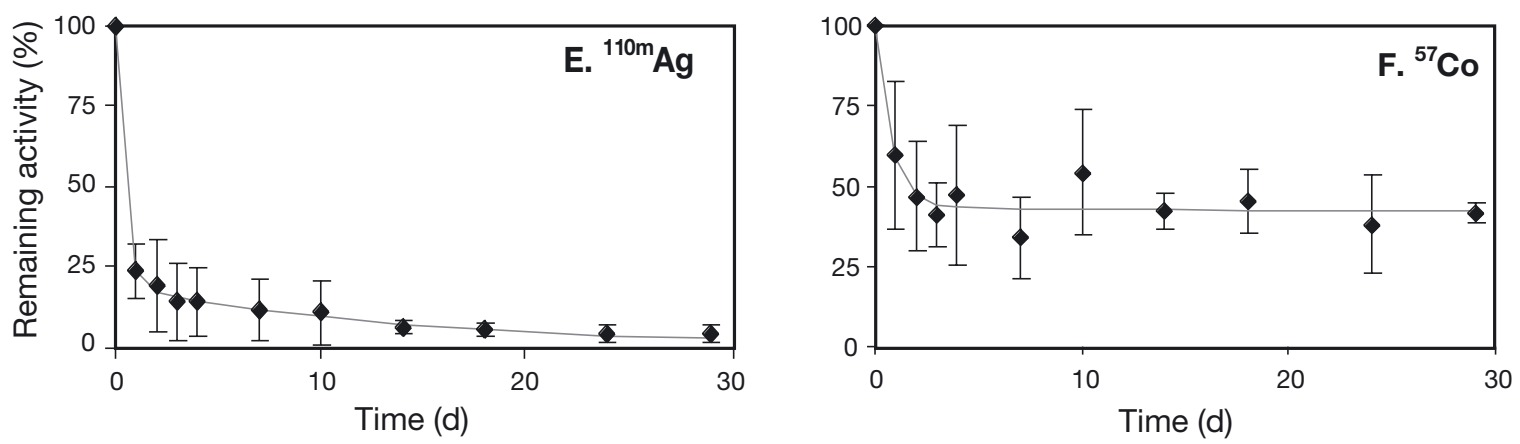

Fig. 4. Sepia officinalis. Whole-body loss kinetics of ${ }^{110 \mathrm{~m}} \mathrm{Ag}$ and ${ }^{57} \mathrm{Co}(\%$ of remaining activity; mean $\pm \mathrm{SD}):(\mathrm{A}, \mathrm{B})$ in juvenile cuttlefish previously exposed to spiked seawater for $36 \mathrm{~h}$ ( $\mathrm{n}=8$ from Days 0 to 20 and $\mathrm{n}=4$ on Day 29); (C,D) in juvenile cuttlefish previously fed radiolabelled brine shrimp Artemia salina ( $\mathrm{n}=8$ from Days 0 to 22 and $\mathrm{n}=5$ on Day 29); ( $\mathrm{E}, \mathrm{F}$ ) in adult cuttlefish previously fed radiolabelled mussels Mytilus galloprovincialis ( $\mathrm{n}=18$ on Day 0, $\mathrm{n}=15$ from Days 1 to $18, \mathrm{n}=12$ from Days 19 to 29). Parameters of the best fitting equations are given in Table 2

contact with seawater generally exhibited a lower \% of the radiotracer after depuration; this was particularly evident for ${ }^{110 \mathrm{~m}} \mathrm{Ag}$ in the gills, head and skin $(\mathrm{p} \leq$ 0.005). It is noteworthy that radioactivity measured in the digestive gland increased from the beginning to the end of the depuration period (factor of 14 for ${ }^{110 \mathrm{~m}} \mathrm{Ag}$ and 3 for ${ }^{57} \mathrm{Co}$ ).

\section{Exposure via the food chain}

In these experiments, juveniles $(n=8)$ were fed radiolabelled adult brine shrimp ad libitum for $1 \mathrm{~h}$ and adult cuttlefish $(\mathrm{n}=18)$ ingested a total of 123 radiolabelled mussels within $2 \mathrm{~h}$. After feeding, the cuttlefish with their ingested prey were immediately $\gamma$-counted for determination of total radiotracer contents (Table 4).

\section{Juveniles}

The loss kinetics of ingested ${ }^{110 \mathrm{~m}} \mathrm{Ag}$ fitted a 2-component exponential model composed of a rapid- and a slow-loss compartment while loss kinetics of ${ }^{57} \mathrm{Co}$ was best described by a single component model 
Table 2. Sepia officinalis. Parameters of the equations describing the loss kinetics of ${ }^{110 \mathrm{~m}} \mathrm{Ag}$ and ${ }^{57}$ Co in whole cuttlefish previously exposed to the radiotracers via different pathways: (a) juveniles previously exposed for $36 \mathrm{~h}$ via seawater; (b) juveniles previously fed radiolabelled brine shrimp Artemia salina; (c) adults previously fed radiolabelled mussels Mytilus galloprovincialis. $\mathrm{O}$ and $\mathrm{T}$ : 1- and 2-exponential loss equations, respectively; ASE: asymptotic standard error; $\mathrm{R}^{2}$ : determination coefficient; p: probability of the model adjustment. For abbreviation definitions, see 'Data and statistical analyses'

\begin{tabular}{|c|c|c|c|c|c|c|c|c|c|}
\hline Pathway & Model & $A_{0 \mathrm{~s}}(\mathrm{ASE})$ & $k_{\mathrm{s}}(\mathrm{ASE})$ & $T_{\mathrm{b}^{1 / 2 \mathrm{~S}}}(\mathrm{~d})$ & $A_{01}(\mathrm{ASE})$ & $k_{1}$ (ASE) & $T_{\mathrm{b}^{1 / 21}}(\mathrm{~d})$ & $\mathrm{R}^{2}$ & $\mathrm{p}$ \\
\hline \multicolumn{10}{|c|}{ (a) Loss in juveniles after seawater exposure } \\
\hline${ }^{110 m} \mathrm{Ag}$ & $\mathrm{O}$ & $100.8(2.5)$ & $0.103(0.006)$ & 6.7 & - & - & - & 0.97 & $<0.001$ \\
\hline${ }^{57} \mathrm{Co}$ & $\mathrm{O}$ & $93.3(2.0)$ & $0.020(0.003)$ & 34 & - & - & - & 0.98 & $<0.001$ \\
\hline \multicolumn{10}{|c|}{ (b) Loss in juveniles after a single feeding on brine shrimp } \\
\hline${ }^{110 m} \mathrm{Ag}$ & $\mathrm{T}$ & $33.8(7.3)$ & $0.668(0.237)$ & 1.0 & $67.2(6.4)$ & $0.053(0.009)$ & 13.2 & 0.82 & $<0.001$ \\
\hline${ }^{57} \mathrm{Co}$ & $\mathrm{O}$ & $98.8(3.1)$ & $0.128(0.100)$ & 5.4 & - & - & - & 0.86 & $<0.001$ \\
\hline \multicolumn{10}{|c|}{ (c) Loss in adults after a single feeding on mussels } \\
\hline${ }^{110 m} \mathrm{Ag}$ & $\mathrm{T}$ & $80.7(3.7)$ & $2.683(0.667)$ & 0.26 & $19.3(3.1)$ & $0.078(0.027)$ & 8.9 & 0.94 & $<0.001$ \\
\hline${ }^{57} \mathrm{Co}$ & $\mathrm{T}$ & $56.9(4.9)$ & $1.290(0.325)$ & 0.54 & $43.2(3.5)$ & $0.001(0.007)$ & 990 & 0.66 & $<0.001$ \\
\hline
\end{tabular}

Table 3. Sepia officinalis. Concentration factors (CF), radiotracer activities (Bq g wet $\mathrm{wt}^{-1}$; mean $\pm \mathrm{SD}$ ) and tissue distribution of radioactivity $(\%$; mean $\pm \mathrm{SD})$ in adult cuttlefish after $8 \mathrm{~h}$ of exposure via seawater $(\mathrm{n}=3)$ and after $6 \mathrm{~d}$ of depuration $(\mathrm{n}=2)$

\begin{tabular}{|c|c|c|c|c|c|c|c|c|c|c|c|}
\hline \multirow{3}{*}{ Tissue } & \multirow{3}{*}{$\%$ wet wt } & \multicolumn{5}{|c|}{$-{ }^{110 \mathrm{~m}} \mathrm{Ag}$} & \multicolumn{5}{|c|}{${ }^{57} \mathrm{Co}$} \\
\hline & & \multicolumn{3}{|c|}{ Accumulation (8 h) } & \multicolumn{2}{|c|}{ Depuration (6 d) } & \multicolumn{3}{|c|}{ Accumulation (8 h) } & \multicolumn{2}{|c|}{ Depuration $(6 \mathrm{~d})$} \\
\hline & & $\mathrm{CF}$ & Activity & $\%$ & Activity & $\%$ & $\mathrm{CF}$ & Activity & $\%$ & Activity & $\%$ \\
\hline $\begin{array}{l}\text { Branchial } \\
\text { heart appendage }\end{array}$ & $\begin{array}{l}0.03 \pm 0.004 \\
\text { es }\end{array}$ & $27 \pm 24$ & $229 \pm 182$ & $<1$ & 51 & $<1$ & $4.7 \pm 1.2$ & $27 \pm 7$ & $<1$ & 81 & $<1$ \\
\hline $\begin{array}{l}\text { Branchial } \\
\text { heart }\end{array}$ & $0.10 \pm 0.02$ & $76 \pm 48$ & $631 \pm 398$ & $<1$ & 316 & $<1$ & $12 \pm 2$ & $70 \pm 12$ & $<1$ & 222 & 2 \\
\hline Gills & $2.3 \pm 0.3$ & $150 \pm 56$ & $1253 \pm 465$ & $25 \pm 6$ & 175 & 3 & $5.1 \pm 1.9$ & $29 \pm 11$ & $4 \pm 1$ & 7 & 1 \\
\hline $\begin{array}{l}\text { Digestive } \\
\text { tract }\end{array}$ & $2.6 \pm 0.6$ & $11 \pm 3$ & $89 \pm 25$ & $2 \pm 1$ & 134 & 4 & $4.7 \pm 0.9$ & $27 \pm 5$ & $4 \pm 1$ & 20 & 5 \\
\hline Genital tract & $3.6 \pm 1.0$ & $4.6 \pm 1.8$ & $39 \pm 15$ & $1 \pm 0$ & 52 & 1 & $6.7 \pm 8.1$ & $39 \pm 47$ & $10 \pm 13$ & 4 & 1 \\
\hline Ink sac & $0.6 \pm 0.2$ & $10 \pm 8$ & $85 \pm 69$ & $<1$ & 26 & $<1$ & $3.2 \pm 0.7$ & $19 \pm 4$ & $1 \pm 0$ & 3 & $<1$ \\
\hline Skin & $6.4 \pm 2.1$ & $40 \pm 16$ & $335 \pm 135$ & $19 \pm 4$ & 144 & 7 & $3.5 \pm 2.3$ & $21 \pm 14$ & $7 \pm 2$ & 6 & 3 \\
\hline $\begin{array}{l}\text { Digestive } \\
\text { gland }\end{array}$ & $4.3 \pm 1.2$ & $17 \pm 14$ & $142 \pm 120$ & $5 \pm 2$ & 2054 & 61 & $15 \pm 13$ & $86 \pm 77$ & $20 \pm 10$ & 280 & 64 \\
\hline Kidney & $0.07 \pm 0.07$ & $17 \pm 12$ & $145 \pm 100$ & $<1$ & 19 & $<1$ & $11 \pm 5$ & $66 \pm 30$ & $<1$ & 27 & $<1$ \\
\hline Muscle & $35 \pm 2$ & $7.3 \pm 3.7$ & $61 \pm 31$ & $18 \pm 2$ & 43 & 13 & $1.6 \pm 0.5$ & $9 \pm 3$ & $19 \pm 1$ & 3 & 9 \\
\hline Head & $40 \pm 1$ & $9.8 \pm 4.3$ & $82 \pm 36$ & $29 \pm 6$ & 30 & 11 & $2.5 \pm 0.7$ & $15 \pm 4$ & $34 \pm 5$ & 5 & 15 \\
\hline Cuttlebone & $5.1 \pm 0.6$ & $0.3 \pm 0.4$ & $3 \pm 3$ & $<1$ & 1 & $<1$ & $0.4 \pm 0.3$ & $2 \pm 2$ & $1 \pm 0$ & 1 & 1 \\
\hline $\begin{array}{l}\text { Whole } \\
\text { cephalopod }\end{array}$ & 100 & $19 \pm 4$ & $112 \pm 42$ & 100 & 120 & 100 & $2.9 \pm 0.8$ & $17 \pm 5$ & 100 & 13 & 100 \\
\hline
\end{tabular}

(Fig. 4C,D, Table 2). The short-lived compartment contained $34 \%$ of the initially ingested ${ }^{110 \mathrm{~m}} \mathrm{Ag}$ activity (Table 2) and was characterised by a $T_{\mathrm{b}^{1 / 2 \mathrm{~s}}}$ of $1 \mathrm{~d}_{\text {; }}$ the long-lived component, representing the proportion of radiotracer actually absorbed by the individuals, had a $T_{\mathrm{b}^{1 / 21}}$ of $13 \mathrm{~d} .{ }^{57} \mathrm{Co}$ was lost with a $T_{\mathrm{b}^{1 / 2}}$ of $5 \mathrm{~d}$ (Table 2). Results showed that both radiotracers were readily assimilated in juveniles with assimilation efficiencies (AE) of $67 \%$ for ${ }^{110 \mathrm{~m}} \mathrm{Ag}$ and $99 \%$ for ${ }^{57} \mathrm{Co}$ (Table 2). Dissections performed 29 d after ingestion indicated that the highest proportion of remaining activity of both tracers occurred in the digestive gland ( $\geq 79 \%$; Table 1).
Adults

The loss kinetics of both ${ }^{110 \mathrm{~m}} \mathrm{Ag}$ and ${ }^{57} \mathrm{Co}$ ingested with food were best described by a 2-component exponential model in adults. As shown in Fig. 4E,F and in Table 2, 81 and $57 \%$ of the ingested activity of ${ }^{110 \mathrm{~m}} \mathrm{Ag}$ and ${ }^{57} \mathrm{Co}$, respectively, were rapidly lost with $T_{\mathrm{b}} 1 / 2 \mathrm{~s}$ of 6 and $13 \mathrm{~h}$. The assimilated fraction of ingested ${ }^{110 \mathrm{~m}} \mathrm{Ag}$ and ${ }^{57} \mathrm{Co}$ was much lower in adults than in juveniles $\left(\mathrm{AE}=19\right.$ vs $67 \%$ for ${ }^{110 \mathrm{~m}} \mathrm{Ag}$ and 43 vs $99 \%$ for $\left.{ }^{57} \mathrm{Co}\right)$. Assimilated ${ }^{57} \mathrm{Co}$ was strongly retained within the tissues of adult cuttlefish; during the observation period, the estimated $T_{\mathrm{b}^{1} / 21}$ was $990 \mathrm{~d}$ (Table 2 ). 
Table 4. Radioactivity (Bq g wet $\mathrm{wt}^{-1}$ or Bq ind. ${ }^{-1}$; mean $\pm \mathrm{SD}$ ) in Mytilus galloprovincialis soft parts and in Artemia salina used as radiolabelled food for adult and juvenile Sepia officinalis, respectively, and radioactivity (Bq; range) in adult and juvenile cuttlefish groups fed these prey

\begin{tabular}{|lcccc|}
\hline Radiotracer & $\begin{array}{c}\text { M. galloprovincialis } \\
(\mathrm{n}=20)\left(\mathrm{Bq} \text { g wet } \mathrm{wt}^{-1}\right)\end{array}$ & $\begin{array}{c}\text { Adult } \text { S. officinalis } \\
(\mathrm{n}=18)(\mathrm{Bq})\end{array}$ & $\begin{array}{c}\text { A. salina } \\
(\mathrm{n}=10)\left(\mathrm{Bq} \text { ind. }{ }^{-1}\right)\end{array}$ & $\begin{array}{c}\text { Juvenile } S \text {. officinalis } \\
(\mathrm{n}=8)(\mathrm{Bq})\end{array}$ \\
\hline${ }^{110 \mathrm{~m}} \mathrm{Ag}$ & $354 \pm 320$ & $167-3144$ & $3.61 \pm 0.07$ & $6.7-23$ \\
${ }^{57} \mathrm{Co}$ & $259 \pm 69$ & $36-730$ & $8.39 \pm 0.08$ & $18-56$ \\
\hline
\end{tabular}

The tissue distribution of ingested radiotracers was determined on several occasions after feeding (Table 5). At the end of the depuration period, both ${ }^{110 \mathrm{~m}} \mathrm{Ag}$ and ${ }^{57} \mathrm{Co}$ were predominantly found in the digestive gland (i.e. 58 and $95 \%$, respectively). The distribution of ${ }^{57} \mathrm{Co}$ among tissues remained unchanged for $29 \mathrm{~d}$ of observation. In contrast, some significant changes were observed for ${ }^{110 \mathrm{~m}} \mathrm{Ag}$ (G-test, $\mathrm{p} \leq 0.01$ ); for example, the proportion of ${ }^{110 \mathrm{~m}} \mathrm{Ag}$ activity decreased in the digestive tract and muscular tissues (mantle muscles and head), while it increased dramatically in the genital tract and ovaries (Table 5).

\section{DISCUSSION}

Published literature regarding Ag and Co concentrations in cephalopod tissues only concerns data from a limited number of field studies (e.g. Martin \& Flegal 1975, Ueda et al. 1979, Miramand \& Bentley 1992, Bustamante et al. 2000, Ishiashi et al. 2001). Cephalopods have been reported to concentrate $\mathrm{Ag}$ and $\mathrm{Co}$, sometimes to high levels, with concentrations up to $84 \mu \mathrm{g} \mathrm{Ag}$ $\mathrm{g}$ dry $\mathrm{wt}^{-1}$ in the digestive gland of squid and $70 \mu \mathrm{g}$ Co $\mathrm{g}$ dry $\mathrm{wt}^{-1}$ in the branchial hearts of octopus (Martin \& Flegal 1975, Ueda et al. 1979). Field data also suggest that the digestive gland plays a important role in the bioaccumulation of these trace metals. Indeed, this organ contains more than $80 \%$ of the total body burden of Ag and Co in the octopus Eledone cirrhosa and in the cuttlefish Sepia officinalis from the English Channel (Miramand \& Bentley 1992), and in the nautilus Nautilus macromphalus from New Caledonia (Bustamante et al. 2000). However, virtually no information is available about the relative importance of the uptake pathways for these elements.

Many cephalopods like the common cuttlefish Sepia officinalis have rapid growth rates, implying intense metabolism and high food intake requirements. Hence, most of them are active predators and have high digestion efficiencies (Boucher-Rodoni et al. 1987). Therefore, food most probably constitutes an important source of trace element uptake for cephalopods. This has been demonstrated experimentally for a few metals and radionuclides; e.g. Cd, $\mathrm{Zn},{ }^{241} \mathrm{Am}$ and ${ }^{237} \mathrm{Pu}$ (Guary \& Fowler 1982, Ueda et al. 1985, Koyama et al. 2000, Bustamante et al. 2002a). Nevertheless, uptake of $\mathrm{Ag}$ and $\mathrm{Co}$ from seawater cannot be neglected, since the whole organism is in close and permanent contact with the ambient medium. In addition, cuttlefish spend most of the daylight period buried into sediment; hence transfer of heavy metals from the sediment should also be considered as a potential uptake pathway.

Table 5. Sepia officinalis. Radiotracer distribution among tissues ( $\%$; mean $\pm \mathrm{SD}, \mathrm{n}=3$ ) of adult cuttlefish 1,18 , and $29 \mathrm{~d}$ after a single feeding on radiolabelled mussels

\begin{tabular}{|c|c|c|c|c|c|c|}
\hline \multirow{2}{*}{ Body compartment } & \multicolumn{2}{|c|}{$1 \mathrm{~d}$} & \multicolumn{2}{|c|}{$18 \mathrm{~d}$} & \multicolumn{2}{|c|}{$-29 \mathrm{~d}$} \\
\hline & ${ }^{110 \mathrm{~m}} \mathrm{Ag}$ & ${ }^{57} \mathrm{Co}$ & ${ }^{110 \mathrm{~m}} \mathrm{Ag}$ & ${ }^{57} \mathrm{Co}$ & ${ }^{110 \mathrm{~m}} \mathrm{Ag}$ & ${ }^{57} \mathrm{Co}$ \\
\hline Branchial heart appendages & $<1$ & $<1$ & $<1$ & $<1$ & $<1$ & $<1$ \\
\hline Branchial heart & $<1$ & $<1$ & $<1$ & $<1$ & $<1$ & $<1$ \\
\hline Gills & $3 \pm 2$ & $<1$ & $3 \pm 1$ & $<1$ & $1 \pm 0$ & $<1$ \\
\hline Digestive tract & $8 \pm 5$ & $3 \pm 1$ & $3 \pm 0$ & $2 \pm 0$ & $2 \pm 1$ & $2 \pm 0$ \\
\hline Genital tract & $2 \pm 1$ & $<1$ & $16 \pm 4$ & $<1$ & $17 \pm 6$ & $1 \pm 0$ \\
\hline Ovary & $2 \pm 2$ & $<1$ & $17 \pm 1$ & $1 \pm 0$ & $19 \pm 7$ & $1 \pm 0$ \\
\hline Ink sac & $<1$ & $<1$ & $<1$ & $<1$ & $<1$ & $<1$ \\
\hline Skin & $2 \pm 1$ & $<1$ & $5 \pm 2$ & $<1$ & $1 \pm 0$ & $<1$ \\
\hline Digestive gland & $60 \pm 23$ & $91 \pm 2$ & $33 \pm 5$ & $95 \pm 1$ & $58 \pm 21$ & $95 \pm 1$ \\
\hline Kidney & $<1$ & $<1$ & $<1$ & $<1$ & $<1$ & $<1$ \\
\hline Muscle & $9 \pm 6$ & $2 \pm 0$ & $14 \pm 5$ & $1 \pm 0$ & $4 \pm 1$ & $1 \pm 0$ \\
\hline Head & $13 \pm 7$ & $3 \pm 1$ & $14 \pm 6$ & $1 \pm 0$ & $4 \pm 1$ & $1 \pm 0$ \\
\hline Cuttlebone & $<1$ & $<1$ & $<1$ & $<1$ & $<1$ & $<1$ \\
\hline
\end{tabular}


Juvenile cuttlefish exposed to spiked sediments for 1 mo accumulated Ag following linear uptake kinetics, suggesting that a steady-state in uptake would take a very long time to achieve under natural conditions. Moreover, uptake of Co from sediment was very low ( $\mathrm{TF} \leq 0.013$ ). Examination of the tissue distribution of both accumulated metals suggests that an efficient translocation occurs from the tissues in direct contact with sediment to the digestive gland, but not to the cuttlebone.

During embryonic development, Ag and Co were efficiently taken up from seawater. However, most of the metals taken up remained associated with the capsule membrane of the eggs. This membrane thus acts as an efficient shield protecting the embryo against direct metal exposure. Similar observations have been reported previously for $\mathrm{Cd}$ and $\mathrm{Zn}$ (Bustamante et al. 2002a). However, for Ag, the capsule-membrane shielding capacity appears to be limited, since after $6 \mathrm{~d}$ Ag was also found in relatively high concentrations within the embryos. In molluscs, it has been established that Ag is not highly toxic for adults (for a review, see Wood et al. 2002), whereas embryos and larvae are very sensitive to the metal (Calabrese et al. 1973, Martin et al. 1981). Such a functional shield for these toxic metals could be an important advantage for organisms that live and reproduce in coastal areas, which are often heavily contaminated by metals. For example, this could be the case in the bay receiving the outflow from the Seine River, where an important population of cuttlefish migrate in spring for mating and breeding. Indeed, very high inputs of Ag in the Bay of Seine were shown to result in high accumulation in the tissues of marine organisms such as the scallop Pecten maximus and the whelk Buccinum undatum (Miramand unpubl. data). Therefore, cephalopod ontogenic development could be affected under such particular environmental conditions.

After a short exposure to radiolabelled seawater (viz. $8 \mathrm{~h}$ ), adult cuttlefish displayed high whole-body activities for both Ag and Co, indicating that both metals are rapidly accumulated from seawater. However, Ag appears to be more bioavailable to cuttlefish than $\mathrm{Co}$, since Ag displayed 6 fold higher CFs. Following seawater exposure, the respiratory tissues, i.e. gills and branchial hearts, displayed the highest ${ }^{110 \mathrm{~m}} \mathrm{Ag}$ activities, whereas digestive gland, kidney and branchial hearts concentrated Co to a greater extent (Table 3). However, in terms of body burden, radiotracers were mainly found in tissues which are in direct contact with seawater (gills and skin accounted for $44 \%$ of the whole-body activity of ${ }^{110 \mathrm{~m}} \mathrm{Ag}$ ) or which represent the main proportion of the total body weight (muscle and head contained $47 \%$ of the total ${ }^{110 \mathrm{~m}} \mathrm{Ag}$ and $50 \%$ of the total ${ }^{57} \mathrm{Co}$ ). Interestingly, the cuttlebone contained the lowest activity among tissues and was the only compartment that always displayed a CF less than one. Similar results $(\mathrm{CF} \leq 0.1)$ have been found for $\mathrm{Cd}$ and $\mathrm{Zn}$ in the cuttlebone of Sepia officinalis (Bustamante et al. 2002a).

After $6 \mathrm{~d}$ of depuration in clean, running seawater, the tissues in direct contact with seawater contained significantly less ${ }^{110 \mathrm{~m}} \mathrm{Ag}$ and ${ }^{57} \mathrm{Co}$ than at the beginning of the depuration period; gills and skin contained only $10 \%$ of the total ${ }^{110 \mathrm{~m}} \mathrm{Ag}$, and the muscular parts contained $24 \%$ of the total radioactivity for both radiotracers (Table 3). These tissues also contained the lowest activities, indicating that previously incorporated tracers were rapidly lost and/or redistributed. In contrast, the digestive gland displayed higher activities of ${ }^{110 \mathrm{~m}} \mathrm{Ag}$ and ${ }^{57} \mathrm{Co}$ (14 and 3 times higher than at the beginning of the depuration period, respectively) and contained more than $60 \%$ of the whole body activity for both radiotracers, indicating an important internal metal translocation to this organ. Therefore, the digestive gland appears to be the main target organ for both $\mathrm{Ag}$ and Co. Due to its stronger retention capacity compared to other tissues, the digestive gland could act as a long-term biological indicator organ for $\mathrm{Ag}$ and $\mathrm{Co}$ contamination.

Branchial hearts also showed a specific affinity for Co as their ${ }^{57} \mathrm{Co}$ activity increased by a factor of 3 during the $6 \mathrm{~d}$ of depuration. These observations are consistent with those made for ${ }^{60} \mathrm{Co}$ in the branchial hearts of the octopus Octopus vulgaris (Nakahara et al. 1979). In addition, Nakahara et al. (1979) suggested that the increase in ${ }^{60} \mathrm{Co}$ in branchial hearts was due to transfer of the nuclide from other parts of the body.

When juveniles were exposed in seawater, subsequent ${ }^{110 \mathrm{~m}} \mathrm{Ag}$ and ${ }^{57} \mathrm{Co}$ release followed a single exponential loss model. Whole-body loss was rapid for ${ }^{110 \mathrm{~m}} \mathrm{Ag}$ but relatively slow for ${ }^{57} \mathrm{Co}\left(T_{\mathrm{b} 1 / 2}: 1\right.$ vs $\left.5 \mathrm{wk}\right)$. After $29 \mathrm{~d}$ of depuration, residual radioactivity of both Ag and Co was mainly located in the digestive gland, suggesting that, like in adults, metal translocations occur from other tissues to the digestive gland. Efficiency of the translocation processes for $\mathrm{Ag}$ and $\mathrm{Co}$ might be responsible of such different retention times noted in cuttlefish.

In the case of dietary exposure, less than $20 \%$ of ingested Ag was assimilated into the tissues of adult cuttlefish. In contrast, Ag was absorbed to a much greater extent in juveniles (AE up to $67 \%$ ). Such a radically different degree of Ag assimilation might be due to differences in digestive metabolism between juvenile and adult cuttlefish (Mangold 1989). In contrast, assimilated Ag was rapidly depurated with similar half-lives in juveniles and adults (i.e. 13 vs 9 d, respectively) which suggests that similar processes govern Ag elimination at both ages. In this context, it appears 
that difference in $\mathrm{AE}$ could also be related to variation in Ag bioavailability due to the different food types ingested by juveniles and adults (brine shrimp vs mussels). Indeed, different metal storage strategies in mussels and brine shrimp could partially control bioavailability owing to different physico-chemical speciation of the metals in the prey (e.g. Reinfelder \& Fisher 1991, Wallace \& Lopez 1997).

The digestive gland clearly plays a major role in the storage of Ag in juveniles and adult cuttlefish. Indeed, regardless of the exposure route, the digestive gland retained most of the metal incorporated. Bivalves such as Pectinidae and Ostreidae have been shown to accumulate very high levels of $\mathrm{Ag}$ in their tissues and to store the contaminant mainly as $\mathrm{Ag}_{2} \mathrm{~S}$, a stable, nontoxic form of Ag (Martoja et al. 1989, Berthet et al. 1992). This detoxified form remains sequestered in the amoebocytes and in the basement membranes of various bivalve organs (Berthet et al. 1990, 1992). The occurrence of sulphydryl-rich proteins such as metallothioneins have been found in the cephalopod digestive gland (Tanaka et al. 1983, Bustamante et al. 2002b). Histochemical and microanalytical investigations in the digestive gland of the cuttlefish Sepia officinalis have shown that $\mathrm{Ag}$ is associated with $\mathrm{Cu}$ and $\mathrm{Zn}$ in spherules accumulated in the basal cells, and these spherules are composed of metallothionein-like proteins (Martoja \& Marcaillou 1993). Metalloproteins play a major role in the homeostasis of $\mathrm{Cu}$ and $\mathrm{Zn}$ and are well known for their capacity to bind $\mathrm{Ag}, \mathrm{Cd}$ and Hg (see e.g. Cosson et al. 1991, George \& Olsson 1994). In the digestive gland of the squid Todarodes pacificus, ca. $60 \%$ of the whole-body burden of Ag is associated mainly with the low molecular weight cytosolic proteins (mol. wt $<20 \mathrm{kDa}$ ) (Tanaka et al. 1983).

Ingested Co was assimilated to a greater extent in juveniles $(99 \%)$ than in adults $(57 \%)$ (Table 2). Furthermore, depuration rate constants were very different between both stages, resulting in very different half-lives, viz. $5 \mathrm{~d}$ for juveniles and $990 \mathrm{~d}$ for adults. Thus, Co appears to be depurated and/or detoxified by completely different processes in juveniles and adults. Such a difference is difficult to explain, since Co is an essential element and has been shown to be easily redistributed to branchial hearts and digestive gland following seawater exposure to the metal (Nakahara et al. 1979, present study). In fact, the very elevated whole-body retention capacity of assimilated Co by adult cuttlefish concerned exclusively the digestive gland, which contained from 91 to $95 \%$ of the total Co body burden. Thus, once incorporated into the adult digestive gland, assimilated Co ingested with prey can be considered as definitively sequestrated. The lower retention efficiency for Co in juvenile cuttlefish could be due to the incomplete development of the digestive gland in early juveniles, as has been suggested for assimilated Cd (Bustamante et al. 2002a). However, although incompletely mature, the digestive gland also plays a role in the storage of Co in juveniles, given that this organ contained $79 \%$ of the whole-body burden of $\mathrm{Ag}$ after $29 \mathrm{~d}$ of loss. Further investigations are needed to better understand the metabolism of Co during the life cycle of cephalopods.

Acknowledgements. We thank Dr. N. Tevenin and Dr. P. Gilles from the Oceanographic Museum of the Principality of Monaco for supplying adult cuttlefish and Dr. S. von Boletzky from the Marine Station of Banyuls, France for providing the cuttlefish eggs. We are also grateful to Dr E. Boucaud-Camou for his advice on culturing cuttlefish. The Marine Environment Laboratory operates under a bipartite agreement between the International Atomic Energy Agency and the Government of the Principality of Monaco. B.D. is holder of a FRIA doctoral grant; M.W. is a Honorary Research Associate of the FNRS, Belgium. We are grateful to the anonymous referees of this manuscript for their critical reviews.

\section{LITERATURE CITED}

Berthet B, Amiard-Triquet C, Martoja R (1990) Effets chimiques et histologiques de la décontamination de l'huitre Crassostrea gigas Thunberg préalablement exposée à l'argent. Water Air Soil Pollut 50:355-369

Berthet B, Amiard JC, Amiard-Triquet C, Martoja R, Jeantet AY (1992) Bioaccumulation, toxicity and physico-chemical speciation of silver in bivalve molluscs: ecotoxicological and health consequences. Sci Total Environ 125:97-122

Boucher-Rodoni R, Boucaud-Camou E, Mangold K (1987) Feeding and digestion. In: Boyle PR (ed) Cephalopod life cycles, Vol II. Comparative reviews. Academic Press, New York

Bustamante P, Cherel Y, Caurant F, Miramand P (1998) Cadmium, copper and zinc in octopuses from Kerguelen Islands, Southern Indian Ocean. Polar Biol 19:264-271

Bustamante P, Grigioni S, Boucher-Rodoni R, Caurant F, Miramand P (2000) Bioaccumulation of 12 trace elements in the tissues of the nautilus Nautilus macromphalus from New-Caledonia. Mar Pollut Bull 40:688-696

Bustamante P, Teyssié JL, Fowler SW, Cotret O, Danis B, Miramand P, Warnau M (2002a) Biokinetics of zinc and cadmium accumulation and depuration at different stages of the life cycle of the cuttlefish Sepia officinalis. Mar Ecol Prog Ser 231:167-177

Bustamante P, Cosson RP, Gallien I, Caurant F, Miramand P (2002b) Cadmium detoxification processes in the digestive gland of cephalopods in relation to accumulated cadmium concentrations. Mar Environ Res 53:227-241

Calabrese A, Collier RS, Nelson DA, MacInnes JR (1973) The toxicity of heavy metals to embryos of the American oyster Crassostrea virginica. Mar Biol 18:162-166

Clarke MR (1996) Cephalopods as prey. III. Cetaceans. Phil Trans R Soc Lond B 351:1053-1065

Cosson RP, Amiard-Triquet C, Amiard JC (1991) Metallothioneins and detoxification. Is the use of detoxification proteins for MTs a language abuse? Water Air Soil Pollut 57/58:555-567

Croxall JP, Prince PA (1996) Cephalopods as prey. I. Seabirds. Phil Trans R Soc Lond B 351:1023-1043 
George SG, Olsson PE (1994) Metallothioneins as indicators of trace metal pollution. In: Kramer KJM (ed) Biomonitoring of coastal waters and estuaries. CRC Press, Boca Raton, FL

Gerpe MS, de Moreno JEA, Moreno VJ, Patat ML (2000) Cadmium, zinc and copper accumulation in the squid Illex argentinus from the Southwest Atlantic Ocean. Mar Biol 136:1039-1044

Guary JC, Fowler SC (1982) Experimental studies on the biokinetics of plutonium and americium in the cephalopod Octopus vulgaris. Mar Ecol Prog Ser 7:327-335

Hubbell SP, Sikora A, Paris OH (1965) Radiotracer, gravimetric and calorimetric studies of ingestion and assimilation rates of an isopod. Health Phys 11:1485-1501

Ishiashi H, Kohno H, Kannan K, Tsumura A, Yamasaki SI (2001) Multielemental analysis of purpleback flying squid using high resolution inductively coupled plasma-mass spectrometry (HR ICP-MS). Environ Sci Technol 35:3103-3108

Klages NTW (1996) Cephalopods as prey. II. Seals. Phil Trans R Soc Lond B 351:1045-1052

Koyama J, Nanamori N, Segawa S (2000) Bioaccumulation of waterborne and dietary cadmium by oval squid Sepioteuthis lessoniana, and its distribution among organs. Mar Pollut Bull 40:961-967

Mangold K (1989) Reproduction, croissance et durée de vie. In: Grassé PP (ed) Traité de zoologie, Tome V. Céphalopodes. Masson, Paris

Martin JH, Flegal AR (1975) High copper concentrations in squid livers in association with elevated levels of silver, cadmium, and zinc. Mar Biol 30:51-55

Martin M, Osborn KE, Billig P, Glickstein N (1981) Toxicities of ten metals to Crassostrea gigas and Mytilus edulis embryos and Cancer magister larvae. Mar Pollut Bull 12: 183-188

Martoja M, Marcaillou C (1993) Localisation cytologique du cuivre et de quelques autres métaux dans la glande digestive de la seiche, Sepia officinalis L. (Mollusque Céphalopode). Can J Fish Aquat Sci 50:542-550

Martoja M, Truchet M, Berthet B (1989) Effets de la contamination expérimentale par l'argent chez Chlamys varia L. (Bivalve Pectinidé). Données quantitatives, histologiques et microanalytiques. Ann Inst Océanogr 65:1-13

Miramand P, Bentley D (1992) Concentration and distribution of heavy metals in tissues of two cephalopods, Eledone cir-

Editorial responsibility: Otto Kinne (Editor),

Oldendorf/Luhe, Germany rhosa and Sepia officinalis, from the French coast of the English Channel. Mar Biol 114:407-414

Miramand P, Guary JC (1980) High concentrations of some heavy metals in tissues of the Mediterranean octopus. Bull Environ Contam Toxicol 24:783-788

Murdoch MH, Chapman PM, Norman DM, Quintino VM (1997) Spiking sediment with organochlorines for toxicity testing. Environ Toxicol Chem 16:1504-1509

Nakahara M, Koyanagi T, Ueda T, Shimizu C (1979) Peculiar accumulation of cobalt- 60 by the branchial hearts of Octopus. Bull Jpn Soc Sci Fish 45:539

Reinfelder JR, Fisher NS (1991) The assimilation of elements ingested by marine copepods. Science 251:794-796

Reinfelder JR, Fisher NS, Luoma SN, Nichols JW, Wang WX (1998) Trace element trophic transfer in aquatic organisms: a critique of the kinetic model approach. Sci Total Environ 219:117-135

Smale MJ (1996) Cephalopods as prey. IV. Fishes. Phil Trans R Soc Lond Ser B 351:1067-1081

Suzuki Y, Nakahara M, Nakamura R (1978) Accumulation of cesium-137 by useful Mollusca. Bull Jpn Soc Sci Fish 44: $325-329$

Tanaka T, Hayashi Y, Ishizawa M (1983) Subcellular distribution and binding of heavy metals in the untreated liver of the squid; comparison with data from the livers of cadmium and silver exposed rats. Experientia (Basel) 39: $746-748$

Ueda T, Nakahara M, Ishii T, Suzuki Y, Suzuki H (1979) Amounts of trace elements in marine cephalopods. J Radiat Res 20:338-342

Ueda T, Nakahara M, Nakamura R, Suzuki Y, Shimizu C (1985) Accumulation of ${ }^{65} \mathrm{Zn}$ by octopus Octopus vulgaris. J Radiation Res 26:313-320

Wallace WG, Lopez GR (1997) Bioavailability of biologically sequestered cadmium and the implications of metal detoxification. Mar Ecol Prog Ser 147:149-157

Whicker FW, Schultz V (1982) Radioecology: nuclear energy and the environment, Vol 2. CRC Press, Boca Raton, FL

Wood CM, La Point TW, Armstrong DE, Birge WJ and 10 others (2002) Biological effects of silver. In: Andren AW, Bober TW (eds) Silver in the environment: transport, fate and effects. SETAC Press, Pensacola, FL

Zar JH (1996) Biostatistical analysis, 3rd edn. Prentice-Hall, Upper Saddle River, NJ

Submitted: September 19, 2003; Accepted: January 20, 2004 Proofs received from author(s): March 3, 2004 